\title{
Editorial: Palynology and Vegetation History
}

\author{
Valentí Rull $^{1 *}$, Encarni Montoya ${ }^{1}$, Thomas Giesecke ${ }^{2}$ and Jesse L. Morris ${ }^{3}$ \\ ${ }^{1}$ Institute of Earth Sciences Jaume Almera (ICTJA), CSIC, Barcelona, Spain, ${ }^{2}$ Department of Palynology and Climate \\ Dynamics, Georg-August Universität Göttingen, Göttingen, Germany, ${ }^{3}$ Department of Geography, University of Utah, Salt \\ Lake City, UT, United States
}

Keywords: palynology, paleoecology, vegetation change, quaternary, environmental change

\section{Editorial on the Research Topic}

\section{Palynology and Vegetation History}

This Research Topic (RT) was conceived as an homage to the Swedish geologist Lennart von Post (1884-1951), the founder of paleoecological palynology, to commemorate the centenary of his presentation of the first modern, quantitative pollen diagram in 1916 at the 16th Convention of Scandinavian Naturalists, held in Kristiania (now Oslo), Norway (Nordlund, 2018). His diagram and its interpretation were published two years later in Swedish (Von Post, 1918) and 51 years later in English (Von Post, 1967). The centenary was celebrated during November 2016, at the Royal Swedish Academy of Sciences in Stockholm, Sweden (Gaillard et al., 2018). Birks and Berglund (2018) summarized the development of Quaternary pollen analysis since von Post's foundational work as occurring in three main phases: (i) the pioneer phase (1916-1950), the building phase (1951-1973) and the mature phase (1974-present). At the beginning, pollen analysis was mainly a stratigraphic tool used for dating and stratigraphic correlation but it later proved to be useful in botanical, biogeographical and ecological research. Since then, palynology has developed into a fundamental tool to unravel the ecological and environmental trends and changes through the Quaternary. In particular, palynology has been instrumental for disentangling natural and anthropogenic drivers of vegetation change, which is needed to understand past and present patterns and processes, and also to predict potential future trends of vegetation in the face of the ongoing climate change.

This RT aimed to provide a thorough view of the use of palynology in aspects such as the reconstruction of Quaternary vegetation and environmental changes, the role of natural and anthropogenic drivers in the development of the Quaternary vegetation, the shaping of present-day ecological and biogeographical patterns, the potential application of this knowledge in biodiversity conservation and landscape restoration and the development of new methods of pollen analysis and data management. The papers published herein cover most of these topics, among others, as the aims and scope were sufficiently broad to include any aspect of modern palynology and its significance for vegetation history. These papers are grouped under four themes. The first two are essentially methodological while the other two provide examples where pollen studies have been applied to investigate ecological dynamics at local, regional and global scales.

\section{MODERN ANALOG STUDIES}

Accepted: 12 October 2018 Published: 02 November 2018

Citation:

Rull V, Montoya E, Giesecke T and Morris JL (2018) Editorial: Palynology and Vegetation History. Front. Earth Sci. 6:186. doi: 10.3389/feart.2018.00186

This section deals with studies where modern pollen assemblages have been applied to aide in the interpretation of past records. In the first paper, Radaeski et al. used a set of standard pollen measurements on $\sim 70$ grass species from Southern Brazil, and found a statistically significant difference between grass pollen from forests vs. open habitat species. The authors conclude that the size of grass pollen grains can be used to discriminate between forest and grassland vegetation in 
past pollen records. The other two studies focused on modern pollen deposition and applications to past records. Florenzano et al. studied the modern deposition of Olea pollen in two regions of Italy and found that most of this pollen type was deposited locally, within olive groves, with sharp declines outside of the cultivated area. These results are used to infer the spatial pattern of olive farming during the Hellenistic, Roman and Medieval periods, on the basis of the Olea pollen preserved in archaeological sites. Yao and Liu studied surface pollen assemblages and soil chemistry along vegetation, edaphic and salinity gradients in the Florida Everglades (USA). Modern pollen spectra correspond perfectly with the vegetation types where samples have been collected. Soil chemistry is consistent with salinity and chemical gradients at local and regional scales.

\section{LAND COVER ESTIMATES FROM POLLEN DATA}

In the last decades, efforts to convert pollen data into quantitative estimates of past vegetation cover have increased, which is reflected here by three contributions. An important prerequisite for inferring past vegetation cover is to estimate the relative pollen production of plants (rPPE), which require detailed modern studies. Theuerkauf and Couwenberg introduce a method, called ROPES, to estimate rPPE's and plant cover from single pollen records with reliable pollen accumulation rates (PAR, in grains $\mathrm{cm}^{-2} \mathrm{y}^{-1}$ ). The principle is that changes in PAR and plant abundance are linearly related. The performance of this method is evaluated and the ROPES advantages and limitations are discussed. Using such or differently derived rPPE's it is then possibly to attempt full landscape reconstructions, which may be achieved using the Multiple Scenario Approach (MSA) presented by Bunting et al. which combines GIS techniques with physical models of pollen dispersion and deposition. They applied the MSA method to two Neolithic sites from Britain and showed that the impact of neolithization on land cover was continuous with no reductions during periods when archaeological evidence suggests lower human activity. In the third paper of this section, Carter et al. use the Landscape Reconstruction Algorithm (LRA) to convert pollen records from Central Europe to forest cover estimates, in order to reconstruct the history of "natural" Holocene forests, as a guide for conservation and restoration practices. These forests have been dominated by spruce for the last 9000 years, which contradicts the prevailing assumption of beech and fir dominance. These latter two species did not reach the region until ca. $6000 \mathrm{cal}$ yr BP, which opens new perspectives for reforestation strategies.

\section{VEGETATION DYNAMICS AND ENVIRONMENTAL DRIVERS}

This section encompasses studies on vegetation dynamics and the associated environmental drivers, notably climate change and anthropogenic activities, from a wide range of biomes and geographical areas including Europe, North and South America, Africa and Oceania.

\section{Europe}

Cheddadi et al. analyzed the response of European forests to Holocene temperature changes and observed that fir showed niche patterns similar to present, whereas beech and spruce occurred at temperature values different from their current ranges. The authors concluded that predictive models of forest distribution should not be based only on modern thermal niches.

\section{North America}

Brunelle et al. provide a regional perspective of the Holocene palynological studies developed by analyzing wetland records from the Desert Southwest (USA). Pollen preservation was useful to infer permanent $v s$. intermittent flood conditions, which the authors interpret to be a proxy for winter precipitation and moisture persistence as controlled by ENSO (El Niño-Southern Oscillation) activity. Therefore, variations in pollen preservation through time can be used as a proxy for past ENSO activity.

\section{Tropical South America}

Montoya et al. present a pollen record from the Ecuadorian Amazonia that documents the composition of premontane Andean forests during the last glaciation, between ca. 50,000 and $20,000 \mathrm{cal}$ yr BP. The decline of formerly dominant trees with a reciprocal increase of heat-intolerant trees from higher Andean environments (Podocarpus, Alnus, Hedyosmum) during the LGM suggests that glacial cooling changed the composition of these Amazon forests by downward migration of sensitive taxa.

\section{Southern South America}

Markgraf presents the very first pollen record of vegetation dynamics from South America (Tierra del Fuego, Argentina), published by Lennart von Post in 1929. The paper reproduces the original diagrams showing a shift from steppe communities to Nothofagus forests, which was interpreted in terms of a climatic shift from warmer/drier to cooler/wetter conditions. Using pollen and charcoal analysis, Moreno et al. evaluate the effect of vegetation and site type on fire regimes in the Chilean Patagonia during the last 13,000 years. Steppe fires were of high frequency and low magnitude, whereas fires occurring in Nothofagus forests were less frequent but more intense. Divergences between fire histories reconstructed from either lake or bog records were attributed to local burning of bog vegetation. Also in Patagonia, Iglesias et al. used independent evidence for environmental, anthropogenic and ecological change to assess the influence of climate and human activities on Holocene vegetation dynamics. Nothofagus-Pilgerodendron forests remained fairly stable between 9000 and $2000 \mathrm{cal} \mathrm{yr} \mathrm{BP,} \mathrm{despite} \mathrm{long-term} \mathrm{changes} \mathrm{in} \mathrm{climate}$ and fire. Local forest fluctuations during the last two millennia were attributed to greater climatic variability and human deforestation.

\section{Africa}

Campbell et al. present a high-resolution reconstruction of Holocene vegetation changes in a semi-arid region from the Moroccan Atlas to gain insights on the response of forests to environmental drivers. Climatic shifts seem to have been more clearly recorded until ca. 4300 cal yr BP, 
when forests started to decline gradually due to increasing pastoralism, fire and aridity. Forests significantly declined by $1300 \mathrm{cal}$ yr BP due to human pressure. Githumbi et al. used multidisciplinary paleoecological, archaeological and historical evidence to understand environmental change and socioecological interactions across the Amboseli National Park (Kenya) during the last 5000 years. The combination of climatic aridity and fire, together with cattle and wild animal activity, have led to changes in woody to grass cover ratio. Especially significant is the recent reduction of woody vegetation and the increase of wetlands due to increasing runoff and flooding.

\section{Oceania}

McGlone et al. review the ecological dynamics of the New Zealand conifers since the LGM, on the basis of the existing pollen records. Conifer forests attained their maximum development by 18,000 years ago and declined during the Holocene, especially after the Māori settlement. The ecological success of conifers is explained in terms of a bimodal ability to endure climatic stress in cool/arid climates and to successfully compete with angiosperms in warmer/wetter environments.

\section{LARGE-SCALE REVIEWS AND META-ANALYSES}

This section includes two studies that use pollen data stored in global databases to address large-scale issues such as continental

\section{REFERENCES}

Birks, H. J. B., and Berglund, B. E. (2018). One hunderd years of Quaternary pollen analysis 1916-2016. Veget. Hist. Archaeobot. 27, 271-309. doi: 10.1007/s00334-017-0630-2

Gaillard, M.-J., Berglund, B. E., Birks, H. J. B., Edwards, K. J., and Bittmann, F. (2018). "Think horizontally, act vertically": the centenary (1916-2016) of pollen analysis and the legacy of Lennart von Post. Veget. Hist. Archaeobot. 27, 267-269. doi: 10.1007/s00334-017-0656-5

Nordlund, C. (2018). Four points on Lennart von Post and the invention of "pollen statistics". Veget. Hist. Archaeobot. 27, 311-317. doi: 10.1007/s00334-017-0628-9

Von Post, L. (1918). “Skogsträdpollen i sydsvenska torvmosselagerföljder," in Forhandlinger ved de Skandinaviske Naturforskeres 16. Møte i Kristiania den 10-15. Juli 1916. Skandinaviska Naturforskaremöten (Oslo), 432-465. forest cover trends and the potential causes of worldwide glaciations. Regarding forests, Zanon et al. used the available pollen records to map the evolution of forest cover on Europe during the last 12,000 years. The general forest cover increased in the Late Glacial-Holocene transition attaining a maximum between 8500 and $6000 \mathrm{cal}$ yr BP, followed by a general decline due to anthropogenic deforestation. The full continental coverage and the spatio-temporal resolution of this reconstruction make it suitable for climatic, hydrological and geochemical modeling. Sánchez-Goñi et al. review the paleoclimatic information contained in long continuous deep-sea pollen records from the European margin, particularly in relation to the interplay among North Atlantic SST, continental ice volume, millennialscale variability and orbital forcing. The authors propose that the interaction between long-term (orbital) and short-term (millennial) climatic variability may have amplified insolation decreases and triggered ice ages.

We hope that this RT will serve to appraise the state of the art of modern palynology and highlight the usefulness of our discipline in long-term ecological research.

\section{AUTHOR CONTRIBUTIONS}

All authors listed have made a substantial, direct and intellectual contribution to the work, and approved it for publication.

Von Post, L. (1967). Forest tree pollen in South Swedish peat bog deposits,
translated by Margaret Bryan Davis and Knut Fægri. Pollen Spores 9, $378-401$.

Conflict of Interest Statement: The authors declare that the research was conducted in the absence of any commercial or financial relationships that could be construed as a potential conflict of interest.

Copyright (C) 2018 Rull, Montoya, Giesecke and Morris. This is an open-access article distributed under the terms of the Creative Commons Attribution License (CC BY). The use, distribution or reproduction in other forums is permitted, provided the original author(s) and the copyright owner(s) are credited and that the original publication in this journal is cited, in accordance with accepted academic practice. No use, distribution or reproduction is permitted which does not comply with these terms. 